\title{
AHP MODEL FOR THE CONTAINER PORT CHOICE IN THE MULTIPLE- PORTS REGION
}

Chien-Chang Chou

Department of Shipping Technology, National Kaohsiung Marines University, Kaohsiung City, Taiwan, R.O.C, chiench1@ms59.hinet.net

Follow this and additional works at: https://jmstt.ntou.edu.tw/journal

Part of the Transportation Engineering Commons

\section{Recommended Citation}

Chou, Chien-Chang (2010) "AHP MODEL FOR THE CONTAINER PORT CHOICE IN THE MULTIPLE-PORTS REGION," Journal of Marine Science and Technology: Vol. 18: Iss. 2, Article 8.

DOI: 10.51400/2709-6998.2321

Available at: https://jmstt.ntou.edu.tw/journal/vol18/iss2/8

This Research Article is brought to you for free and open access by Journal of Marine Science and Technology. It has been accepted for inclusion in Journal of Marine Science and Technology by an authorized editor of Journal of Marine Science and Technology. 


\section{AHP MODEL FOR THE CONTAINER PORT CHOICE IN THE MULTIPLE-PORTS REGION}

\section{Acknowledgements}

The authors thankful to the referee for his valuable comments on the earlier draft of the paper. The authors sincerely acknowledge the financial assistance by the University Grants Commission, New Delhi, INDIA under the major research project No. F.31-84/2005(SR). 


\title{
AHP MODEL FOR THE CONTAINER PORT CHOICE IN THE MULTIPLE-PORTS REGION
}

\author{
Chien-Chang Chou*
}

Key words: AHP method, port choice, port management, containerization.

\begin{abstract}
The port choice in the multiple-ports region is one of important issues in the international trade container transportation system. In order to reduce the total transportation cost, it is very important for shipping carriers to choose an optimal port for callings. The aim of this paper is to construct an Analytic Hierarchy Process (AHP) model for simulating the behaviors of carriers' port choice and identifying the importance weight of every influential factor influencing carriers' port choices in the multiple-ports region. Finally, the utilization of this proposed AHP model is demonstrated with a case of five shipping companies. By the AHP model, we can obtain the importance weight of every factor influencing the decision-making of carriers' port choices. The findings might be of interest to port managers and government departments of marine transportation. Based on these findings, port managers can further make some useful operation strategies and government departments of marine transportation also can make some important port policies to improve the competitiveness of ports and to attract more containership' callings.
\end{abstract}

\section{INTRODUCTION}

There are three major international container ports in Taiwan, including the Keelung port in the North Taiwan area, the Taichung port in the Central Taiwan area and the Kaohsiung port in the South Taiwan area, respectively. In 2006, almost $42 \%(3,191,955$ TEUs) of the total volume of Taiwan's exported and imported international trade containers is from/to the North Taiwan area, $23 \%(1,747,975$ TEUs) is from/to the Central Taiwan area and 35\% (2,659,962 TEUs) is from/to the South Taiwan area, respectively. The Kaohsiung port has bigger container yards, deeper berths, lower container handling charges, higher operation efficiency, larger volumes of containers, and higher frequency of ship calls than those of the

Paper submitted 09/05/08; revised 05/22/09; accepted 05/26/09. Author for correspondence: Chien-Chang Chou (e-mail: chiench1@ms58.hinet.net).

*Department of Shipping Technology, National Kaohsiung Marines University, Kaohsiung City, Taiwan, R.O.C.
Keelung port and the Taichung port. As a result, in 2006 the container throughput splits for the Keelung port, the Taichung port and the Kaohsiung port are 26.04\% (1,979,246 TEUs), $12.26 \%$ (931,864 TEUs) and $61.70 \%$ (4,688,782 TEUs) respectively. That is, more $1,200,000$ TEUs international trade containers from/to the North Taiwan area have to be exported/ imported via the Kaohsiung port in the South Taiwan area. Table 1 and Fig. 1 provide the volumes of import, export and transshipment containers for the Keelung port, Taichung port and Kaohsiung port from 1981 to 2006. The basic data for the Keelung port, Taichung port and Kaohsiung port is also shown in Table 2.

A containership involves a major capital investment, the daily operating costs e.g. the fuel cost, the crew salary, and the depreciation cost. The daily operating costs of a large containership may amount to thousands of US dollars. To select an optimal container port for containership calling could yield great potential of improving their economic performance and costs saving. What port managers and the government departments of marine transportation are interested is the behaviors of port choices of shipping carriers. If they could understand the decision-making procedure and the importance weight of every influential factor in the decision-making of carriers' port choices, the port managers can further make some proper operation strategies to improve the service quality of port, and the government departments of marine transportation also can make new policies to improving ports' competitiveness and to attract more containership' callings. The aim of this paper is to construct a model for simulating the behaviors of shipping carriers' port choices and identifying the importance weight of every influential factor in the decision-making of carriers' port choices.

The rest of this paper is organized as follows. The literature review is shown in Section II. In Section III this paper constructs an AHP model for simulating the behaviors of carriers' port selection. And then the proposed AHP model is tested by a case study of five shipping companies. The discussion is provided in Section IV. Finally, some conclusions are given in Section V.

\section{LITERATURE REVIEW}

\section{Literature Review of Port Choice}

Many influential factors are considered for the selection of 
Table 1. Import, export and transshipment container volumes for Keelung port, Taichung port and Kaohsiung port.

\begin{tabular}{|c|c|c|c|c|c|c|c|c|c|c|}
\hline \multirow{3}{*}{ Year } & \multirow{2}{*}{\multicolumn{5}{|c|}{ Keelung port }} & \multirow{2}{*}{\multicolumn{5}{|c|}{ Kaohsiung port }} \\
\hline & & & & & & & & & & \\
\hline & Export & Import & Transship & Exp. + Imp. & Total & Export & Import & Transship & Exp. + Imp. & Total \\
\hline 1981 & 321,993 & 333,437 & 0 & 655,430 & 655430 & 547,983 & 496,217 & 0 & $1,044,200$ & $1,044,200$ \\
\hline 1982 & 342,130 & 359,100 & 0 & 701,230 & 701230 & 559,131 & 535,325 & 0 & $1,094,456$ & $1,094,456$ \\
\hline 1983 & 451,899 & 452,049 & 38,578 & 903,948 & 942526 & 617,527 & 587,800 & 256,309 & $1,205,327$ & $1,461,636$ \\
\hline 1984 & 598,133 & 573,384 & 62,277 & $1,171,517$ & 1233794 & 629,836 & 619,865 & 535,282 & $1,249,701$ & $1,784,983$ \\
\hline 1985 & 591,471 & 528,718 & 37,651 & $1,120,189$ & 1157840 & 682,812 & 684,029 & 534,012 & $1,366,841$ & $1,900,853$ \\
\hline 1986 & 785,729 & 717,883 & 91,000 & $1,503,612$ & 1594612 & 890,911 & 949,393 & 642,171 & $1,840,304$ & $2,482,475$ \\
\hline 1987 & 962,873 & 866,257 & 110,688 & $1,829,130$ & 1939818 & 905,633 & 910,871 & 962,304 & $1,816,504$ & $2,778,808$ \\
\hline 1988 & 882,730 & 793,343 & 85,620 & $1,676,073$ & 1761693 & 983,530 & 997,247 & $1,102,039$ & $1,980,777$ & $3,082,816$ \\
\hline 1989 & 872,512 & 798,730 & 100,687 & $1,671,242$ & 1771929 & $1,053,311$ & $1,077,952$ & $1,251,228$ & $2,131,263$ & $3,382,491$ \\
\hline 1990 & 909,366 & 823,492 & 107,917 & $1,732,858$ & 1840775 & $1,068,178$ & $1,084,875$ & $1,341,565$ & $2,153,053$ & $3,494,618$ \\
\hline 1991 & 997,201 & 899,738 & 110,811 & $1,896,939$ & 2007750 & $1,172,798$ & $1,228,795$ & $1,541,497$ & $2,401,593$ & $3,943,090$ \\
\hline 1992 & 964,415 & 893,729 & 82,440 & $1,858,144$ & 1940584 & $1,251,611$ & $1,249,357$ & $1,459,593$ & $2,500,968$ & $3,960,561$ \\
\hline 1993 & 922,210 & 876,610 & 87,604 & $1,798,820$ & 1886424 & $1,420,649$ & $1,378,208$ & $1,726,071$ & $2,798,857$ & $4,524,928$ \\
\hline 1994 & 952,350 & 950,100 & 144,122 & $1,902,450$ & 2046572 & $1,466,009$ & $1,381,511$ & $2,052,341$ & $2,847,520$ & $4,899,861$ \\
\hline 1995 & 979,370 & 997,059 & 188,763 & $1,976,429$ & 2165192 & $1,475,603$ & $1,400,308$ & $2,177,257$ & $2,875,911$ & $5,053,168$ \\
\hline 1996 & 963,775 & 984,312 & 160,489 & $1,948,087$ & 2108576 & $1,528,996$ & $1,451,008$ & $2,083,044$ & $2,980,004$ & $5,063,048$ \\
\hline 1997 & 919,134 & 955,584 & 110,758 & $1,874,718$ & 1985476 & $1,621,285$ & $1,566,349$ & $2,505,706$ & $3,187,634$ & $5,693,340$ \\
\hline 1998 & 768,956 & 865,853 & 72,068 & $1,634,809$ & 1706877 & $1,677,115$ & $1,501,556$ & $3,092,382$ & $3,178,671$ & $6,271,053$ \\
\hline 1999 & 744,739 & 845,789 & 75,094 & $1,590,528$ & 1665622 & $1,795,244$ & $1,600,993$ & $3,589,128$ & $3,396,237$ & $6,985,365$ \\
\hline 2000 & 862,422 & 997,255 & 94,902 & $1,859,677$ & 1954579 & $1,852,344$ & $1,607,875$ & $3,965,616$ & $3,460,219$ & $7,425,835$ \\
\hline 2001 & 808,695 & 884,308 & 122,855 & $1,693,003$ & 1815858 & $1,803,011$ & $1,616,896$ & $4,120,623$ & $3,419,907$ & $7,540,530$ \\
\hline 2002 & 889,385 & 924,762 & 104,450 & $1,814,147$ & 1918597 & $1,982,912$ & $1,690,863$ & $4,819,277$ & $3,673,775$ & $8,493,052$ \\
\hline 2003 & 903,891 & 980,352 & 116,463 & $1,884,243$ & 2000706 & $2,015,254$ & $1,797,505$ & $5,030,606$ & $3,812,759$ & $8,843,365$ \\
\hline 2004 & 946,441 & $1,029,400$ & 94,351 & $1,975,841$ & 2070192 & $2,279,956$ & $2,399,480$ & $5,034,680$ & $4,679,436$ & $9,714,116$ \\
\hline 2005 & 954,235 & $1,026,361$ & 110,861 & $1,980,596$ & 2091457 & $2,298,732$ & $2,392,396$ & $4,779,928$ & $4,691,128$ & $9,471,056$ \\
\hline 2006 & 964,488 & $1,014,758$ & 149,569 & $1,979,246$ & $2,128,815$ & $2,323,432$ & $2,365,350$ & $5,085,888$ & $4,688,782$ & $9,774,670$ \\
\hline
\end{tabular}

\begin{tabular}{|c|c|c|c|c|c|c|c|c|c|c|}
\hline & \multicolumn{5}{|c|}{ Taichung port } & \multicolumn{5}{|c|}{ Total Volume for these three ports } \\
\hline Year & Export & Import & Transship & Exp. + Imp. & Total & Export & Import & Transship & Exp. + Imp. & Total \\
\hline 1981 & 3,682 & 3,927 & 0 & 7,609 & 7,609 & 873,658 & 833,581 & 0 & $1,707,239$ & $1,707,239$ \\
\hline 1982 & 2,863 & 2,118 & 0 & 4,981 & 4,981 & 904,124 & 896,543 & 0 & $1,800,667$ & $1,800,667$ \\
\hline 1983 & 3,063 & 3,985 & 0 & 7,048 & 7,048 & $1,072,489$ & $1,043,834$ & 294,887 & $2,116,323$ & $2,411,210$ \\
\hline 1984 & 3,806 & 4,259 & 0 & 8,065 & 8,065 & $1,231,775$ & $1,197,508$ & 597,559 & $2,429,283$ & $3,026,842$ \\
\hline 1985 & 8,287 & 8,171 & 0 & 16,458 & 16,458 & $1,282,570$ & $1,220,918$ & 571,663 & $2,503,488$ & $3,075,151$ \\
\hline 1986 & 17,032 & 18,047 & 0 & 35,079 & 35,079 & $1,693,672$ & $1,685,323$ & 733,171 & $3,378,995$ & $4,112,166$ \\
\hline 1987 & 26,607 & 27,089 & 0 & 53,696 & 53,696 & $1,895,113$ & $1,804,217$ & $1,072,992$ & $3,699,330$ & $4,772,322$ \\
\hline 1988 & 51,406 & 44,569 & 0 & 95,975 & 95,975 & $1,917,666$ & $1,835,159$ & $1,187,659$ & $3,752,825$ & $4,940,484$ \\
\hline 1989 & 58,648 & 49,918 & 0 & 108,566 & 108,566 & $1,984,471$ & $1,926,600$ & $1,351,915$ & $3,911,071$ & $5,262,986$ \\
\hline 1990 & 69,153 & 58,919 & 0 & 128,072 & 128,072 & $2,046,697$ & $1,967,286$ & $1,449,482$ & $4,013,983$ & $5,463,465$ \\
\hline 1991 & 108,063 & 100,640 & 0 & 208,703 & 208,703 & $2,278,062$ & $2,229,173$ & $1,652,308$ & 07,235 & $6,159,543$ \\
\hline 1992 & 143,260 & 133,563 & 0 & 276,823 & 276,823 & $2,359,286$ & $2,276,649$ & $1,542,033$ & $4,635,935$ & $6,177,968$ \\
\hline 1993 & 158,485 & 142,141 & 0 & 300,626 & 300,626 & $2,501,344$ & $2,396,959$ & $1,813,675$ & $4,898,303$ & $6,711,978$ \\
\hline 1994 & 181,321 & 172,287 & 0 & 353,608 & 353,608 & $2,599,680$ & $2,503,898$ & $2,196,463$ & $5,103,578$ & $7,300,041$ \\
\hline 1995 & 217,117 & 211,069 & 0 & 428,186 & 428,186 & $2,672,090$ & $2,608,436$ & $2,366,020$ & $5,280,526$ & $7,646,546$ \\
\hline 1996 & 286,407 & 260,278 & 148,122 & 546,685 & 694,807 & $2,779,178$ & $2,695,598$ & $2,391,655$ & $5,474,776$ & $7,866,431$ \\
\hline 1997 & 358,832 & 334,991 & 148,152 & 693,823 & 841,975 & $2,899,251$ & $2,856,924$ & $2,764,616$ & $5,756,175$ & $8,520,791$ \\
\hline 1998 & 366,999 & 353,947 & 159,299 & 720,946 & 880,245 & $2,813,070$ & $2,721,356$ & $3,323,749$ & $5,534,426$ & $8,858,175$ \\
\hline 1999 & 434,644 & 416,872 & 255,155 & 851,516 & $1,106,671$ & $2,974,627$ & $2,863,654$ & $3,919,377$ & $5,838,281$ & $9,757,658$ \\
\hline 2000 & 426,077 & 425,094 & 279,192 & 851,171 & $1,130,363$ & $3,140,843$ & $3,030,224$ & $4,339,710$ & $6,171,067$ & $10,510,777$ \\
\hline 2001 & 401,491 & 398,319 & 269,551 & 799,810 & $1,069,361$ & $3,013,197$ & $2,899,523$ & $4,513,029$ & $5,912,720$ & $10,425,749$ \\
\hline 2002 & 517,312 & 496,212 & 180,133 & $1,013,524$ & $1,193,657$ & $3,389,609$ & $3,111,837$ & $5,103,860$ & $6,501,446$ & $11,605,306$ \\
\hline 2003 & 455,242 & 434,594 & 356,191 & 889,836 & $1,246,027$ & $3,374,387$ & $3,212,451$ & $5,503,260$ & $6,586,838$ & $12,090,098$ \\
\hline 2004 & 476,046 & 441,949 & 327,190 & 917,995 & $1,245,185$ & $3,702,443$ & $3,870,829$ & $5,456,221$ & $7,573,272$ & $13,029,493$ \\
\hline 2005 & 464,561 & 448,180 & 316,174 & 912,741 & $1,228,915$ & $3,717,528$ & $3,866,937$ & $5,206,963$ & $7,584,465$ & $12,791,428$ \\
\hline 2006 & 473,858 & 458,006 & 266,666 & 931,864 & $1,198,530$ & $3,761,778$ & $3,838,114$ & $5,502,123$ & $7,599,892$ & $13,102,015$ \\
\hline
\end{tabular}

Source: Annual statistical reports of Keelung Port, Taichung Port and Kaohsiung Port, Taiwan, Republic of China. 


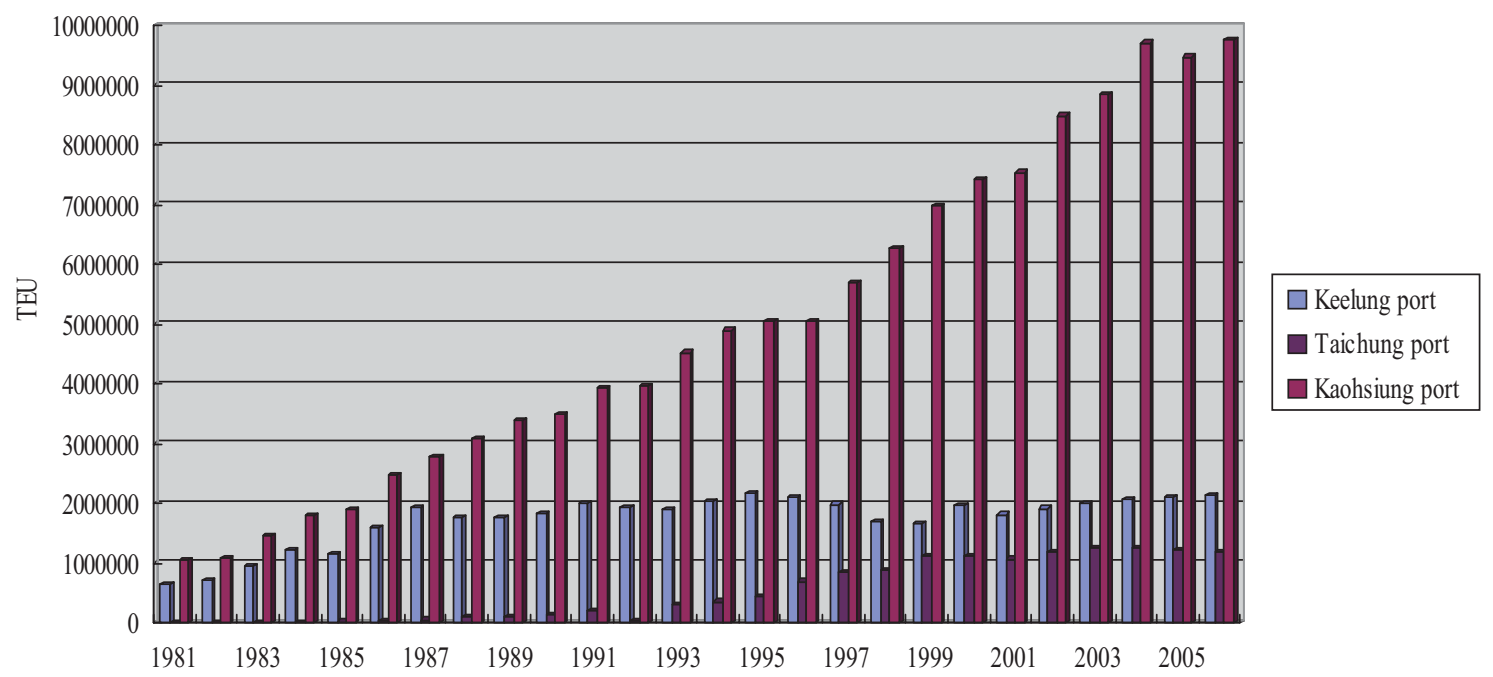

Fig. 1. The container volumes for Keelung port, Taichung port and Kaohsiung port.

Table 2. Basic data for Keelung port, Taichung port and Kaohsiung port.

\begin{tabular}{lcrr}
\hline & Keelung port & Taichung port & Kaohsiung port \\
\hline Total port area (hectare) & 627 & 4295 & 2396 \\
Container yard area (hectare) & 20 & 49 & 238 \\
Depth of berth (m) & 13 & 14 & 16 \\
Number of container quay & 15 & 7 & 26 \\
Container quay operation by & Keelung port & Taichung port & shipping companies \\
Hinterland economy (\%) & 42 & 23 & 35 \\
$\quad$ (import \& export) & 26 & 12 & 62 \\
Container throughput split (\%) & 16 & 9 & 75 \\
$\quad$ Volume of loading/discharging containers (\%) & \multicolumn{2}{c}{32} \\
$\quad$ (import \& export \& transshipment containers) & 27 & 30 & 32 \\
\hline
\end{tabular}

Source: Annual statistical reports of Keelung Port, Taichung Port and Kaohsiung Port, Taiwan, Republic of China.

container port. Hayuth [15] proposed the most common characteristics of a port are related to: (a) location (good foreland and hinterland accessibility and large hinterland), (b) operation (high productivity, frequent port of call, reasonable transportation and port-user costs, high cargo-generating effect and high level of inter-modality), (c) infrastructure (state of the art infrastructure and superstructure, large back up space on terminal) and (d) degree of integration (EDI).

Brian [1] used the following 11 criteria for port selection: (a) port security, (b) size of port, (c) inland freight rates, (d) port charges, (e) quality of customs handling, (f) free time, (g) congestion, (h) port equipment, (i) number of sailings, (j) proximity of port, (k) possibility of inter-modal links.

Jansson and Shneers [18] concluded that a shuttle-service/ sea-feeder transportation seems worthwhile only in exceptional cases where these route characteristics co-exist: (a) a very low trade density which require a very wide service range relative to the coast-to-coast distance, (b) a large proportion of the total cargo is generated in the hinterland of the base port, (c) the ports are situated deep into the country along a muchindented coast or on scattered islands of an archipelago.

James and Gail [17] voice the widespread belief that frequency of shipping service is a main reason for choice of seaport in cargo movement. Time on the route and labor problems at ports is major concerns of freight forwarders. The above-mentioned factors also could be included in the criteria for the selection of ports.

Thomson [29] found that the key successful factors of the transshipment port including: (a) length of berthing time port, (b) loading/discharge rate, (c) available number of berths, (d) quantity of containerized cargo, (e) port facility, (f) links of port to major consumers market, (g) working hours of ports. Sternberg [26] stated that the key successful factors of a transshipment port are as follows: (a) superior geographical location, (b) knowledge of market of marine container operators, (c) flexible operation process, (d) continuous invest- 
ment in the infrastructure and facility, (e) operation of related business.

Brooks [2] suggested that coast and coverage are not the only drivers of the network configuration decision. A carrier's optimal port call structure is not only a function of voyage distance, steaming time, or port time, but also a complicated interplay of these operational factors with shippers' needs for transit time, service frequency, special equipment, or other service elements.

Ernst [13] found that to achieve large scale transshipment requires: (a) increase in service frequency, (b) build up of shipping and inter-modal alliance, and (c) sharing of space on each other's ships, inland depots, feeders, container terminals, and container inventories.

Malchow and Kanafani [21] used an alternative form of the discrete choice model to analyze the distribution of maritime shipments among US ports. They modeled the distribution as a function of the characteristics that describe each shipment and each port. Finally, they found that the most significant characteristics of a port is its location.

Tongzon and Sawant [32] developed a model for port choice of the shipping lines based on a revealed preference approach. The empirical study is based on a survey conducted among major shipping lines operating in Singapore and Malaysia. The findings have shown port charges and wide range of port services to be the only significant factors in their port choice.

Chou [6] found out factors that influent Asia-America oceangoing carriers' port choices are different from those that influent Intra-Asia coasting carriers' port choices. Chou et al. [10] discussed the influential factor in the port choice and proposed a modified regression model for forecasting the import container volumes of ports in Taiwan.

Chang et al. [3] identified the factors affecting shipping companies' port choice based on a survey to a sample of shipping companies. Six factors were considered relatively important: local cargo volume, terminal handling charge, berth availability, port location, transshipment volume and feeder network.

Tongzon [31] evaluated the major factors influencing port choice from the Southeast Asian freight forwarders' perspective. Efficiency is found to be the most important factor followed by shipping frequency, adequate infrastructure and location.

Based on the above-mentioned factors that influence oceangoing and coasting carriers' port choice, a hierarchical analysis structure for port selection is shown in Fig. 2.

\section{Literature Review of Methodology}

Many research methods for port choice have been developed and proposed. Yang [33] formulates a Stackerlberg mathematical programming model for port choice. Kuo and Chu [20] construct a decision-making model for the selection of calling container port using mathematical programming method. Chou [4] analyzes the competitiveness of container ports by Strength Weakness Opportunity and Threat (SWOT) analysis method and identifies some important factors that influent the container port choice. Chou et al. [7, 8] discuss some important factors that influent the selection of container port and develop a transportation demand split model for international ports by mathematical programming. Chou et al. [9] also discusses some important factors that influent the selection of container port and constructs a mathematical programming Equilibrium model for port choice, then further compares the Stackerlberg port choice model with the Equilibrium port choice model. Unfortunately, most of the above-mentioned papers proposing port choice models by mathematical programming method cannot be used to explain the actual decision-making of carriers' port choice. Chou [5] used an analytic hierarchy process approach to the selection of port in a multiple-ports region. Chou [6] developed a model for port choice by using fuzzy multiple criteria decision-making (MCDM) approach.

The port choice problem is also one of location selection problems. Many methods for location selection have been developed. Dahlberg and May [12] utilized the simplex method to determine the optimal location of energy facilities. Tompkins and White [30] introduced a method that used the preference theory to assign weights to subjective factors by making all possible pair wise comparisons between factors. Spohrer and Kmak [25] proposed a weight factor analysis method to integrate the quantitative data and qualitative ratings to choose a plant location from numerous alternatives. Stevenson [27] proposed a cost-volume analysis method to select the best plant location. Multiple criteria decision-making (MCDM) methods were also provided to deal with the problem of ranking and selecting locations under multiple criteria decision-making environment [16, 23]. Chu and Lai [11] proposed an improved fuzzy MCDM approach to the selection of distribution centre location. Mourmouris [22] developed a multiple criteria methodological framework for the evaluation of alternative sites of waste treatment facilities, which will support the decision making process. Farahani and Asgari [14] used a MCDM model to select facility locations. Kuo et al. [19] presented a new method of analysis of multi-criteria based on the incorporated efficient fuzzy model and concepts of positive ideal and negative ideal points to solve location selection problems with multi-judges and multi-criteria in real-life situations. Tabari et al. [28] proposed a hybrid method of multiple criteria decision making that make it possible to select the optimal location that satisfies the decision maker.

In general, the selection of an optimal container port for ship's calling from among two or more alternatives ports on the basis of two or more factors is an assigning importance weight of factors and multiple criteria decision-making problem. The AHP approach not only can be used to deal with the importance weights of factors and multiple criteria decision-making problems, but also the AHP approach can further be sure the accuracy and consistency of questionnaire survey by the Consistency Ratio test. Thus an AHP approach for solving the container port selection problem in the multiple- 


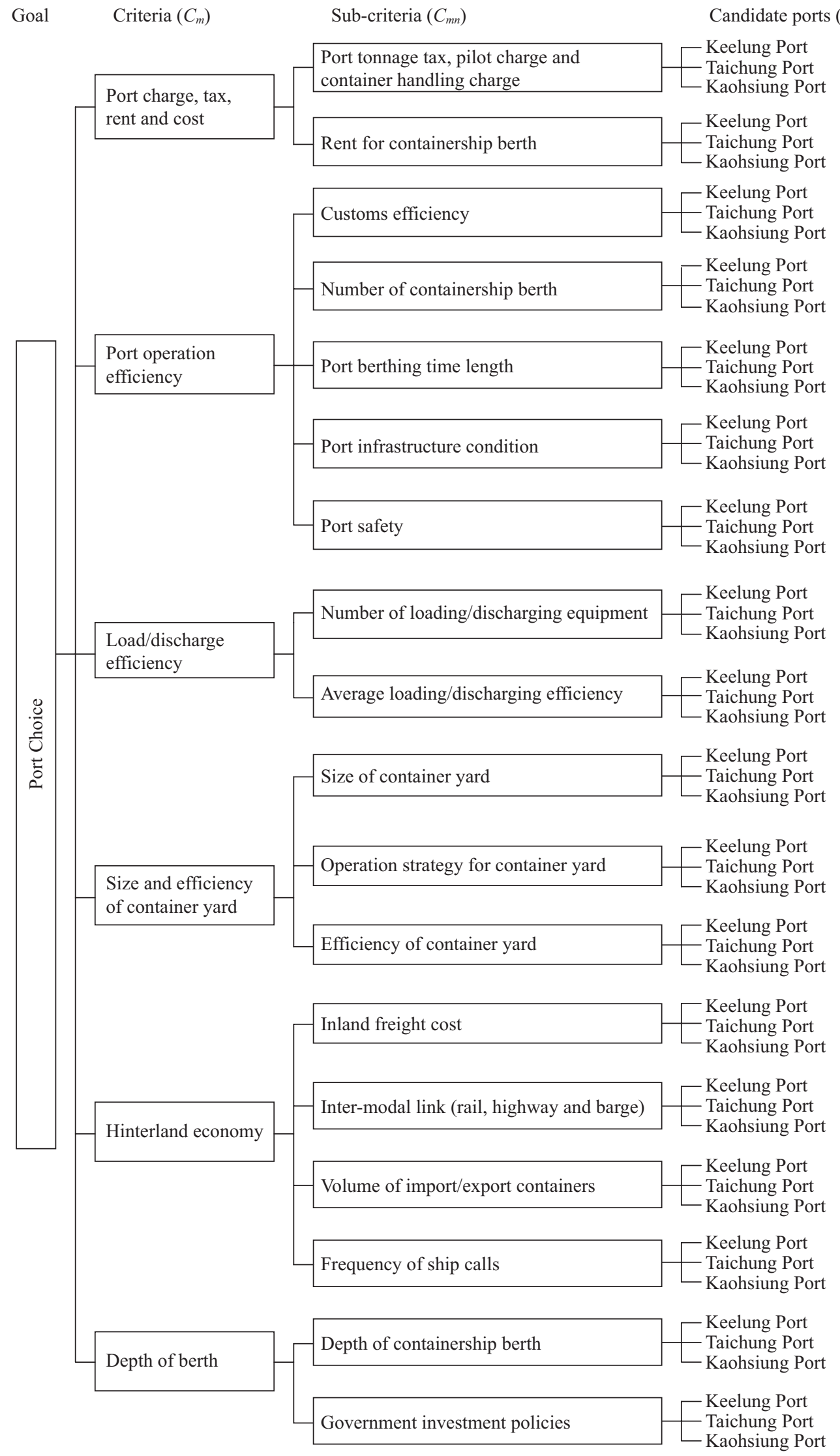

Fig. 2. Hierarchical analysis structure for selection of container port. 
Table 3. Survey data for comparative weights for each criteria.

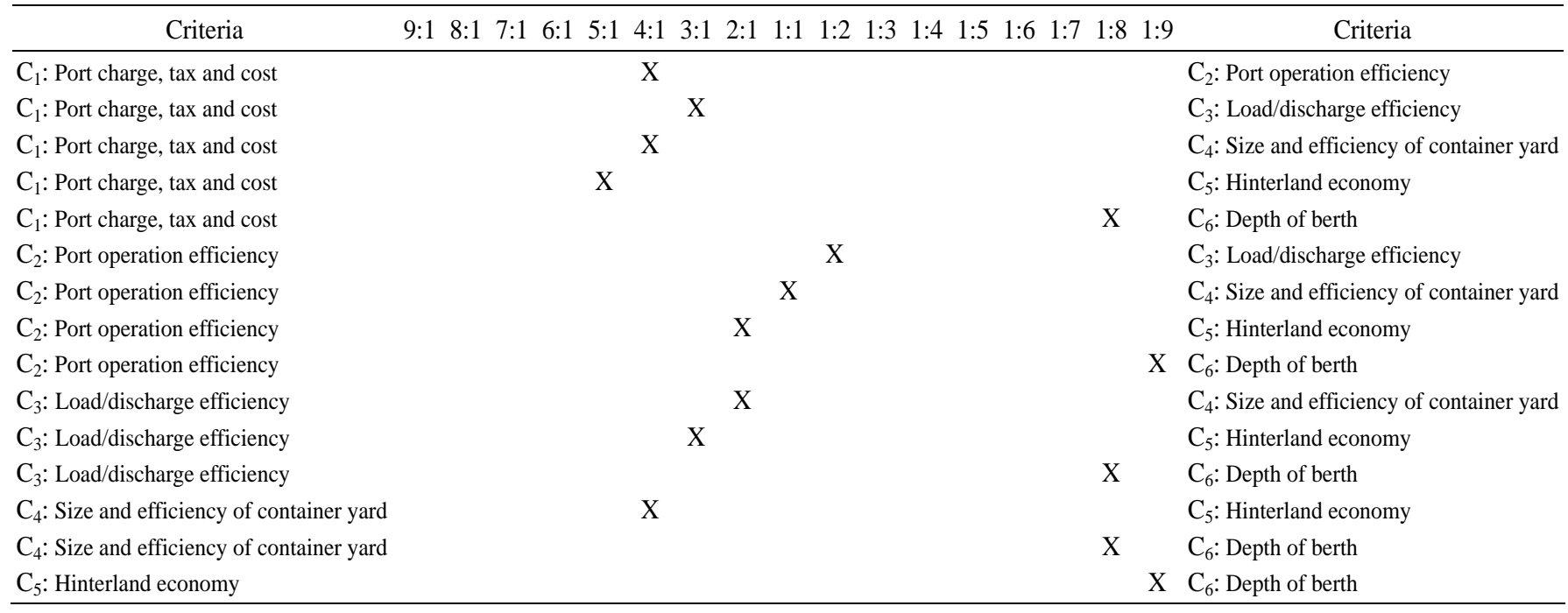

ports region under multiple criteria decision-making situation is conducted in this study.

\section{AHP MODEL FOR PORT CHOICE}

\section{Survey Development and Data Collection}

In general, there are three steps in the port choice procedure. First, shipping companies investigate the origin destination (O-D) of cargo, gather information about the behavior of shippers, make an estimation of the flow of cargo. Second, shipping companies planning several candidate ports for containership calling. The several candidate ports are provided to the top decision maker of shipping company. Finally the top decision maker chooses an optimal port for ship calling. That is, the decision making of the selection of container port is not made by a committee of many decision makers, but by the top decision maker of the shipping company.

To investigate carriers' decision-making procedure for port choices, personal interviews were conducted with 5 top decision makers of five shipping companies, hereinafter called A Marine Corp., B Marine Corp., C Marine Corp., D Marine Corp., and E Lines Ltd. The five shipping companies were divided into two categories: the oceangoing routes and the coasting routes. A, B, C, and D four shipping companies operate oceangoing routes including Asia-European, Asia-America and America-European routes. E shipping company operates coasting route including Southeast Asia-Northeast Asia routes.

Based on Fig. 2, one interview questionnaire was designed for use at the five shipping companies served as the primary measurement tools in this investigation. The intent was to identify the importance weights of criteria, the importance weights of sub-criteria and the preferences for candidate ports in the port choice decision-makings of oceangoing route and coasting route carriers.

Personalized, one-on-one interviews using the survey form were performed in compliance with traditional survey and interview protocols. A pilot test of the survey for oceangoing routes was conducted at A Marine Corp. in Kaohsiung city, Taiwan, to ensure that the top decision maker accurately understood the questions and that desired information about the port choice decision-making for oceangoing routes was obtained. Another pilot test of the survey for coasting routes was conducted at E Lines Ltd. in Kaohsiung city, to ensure that the top decision maker accurately understood the questions and that desired information about the port choice decision- making for coasting routes was obtained. The structure of the final questionnaire covers topics ranging from general information about the shipping companies to specific information about the importance weights of criteria, and the preferences for alternative ports. Following the pilot test, personalized, oneon-one interviews using the final survey form were performed. The 5 top decision makers of A, B, C, D, and E shipping companies were interviewed in Kaohsiung city.

Once the survey data for port choice decision-making were collected as Tables 3 and 4, the importance weights for each criteria and sub-criteria were calculated by the AHP technique and were presented in Section III.3. The top decision maker of the shipping company can further rank all candidate ports in Taiwan area and then select the best one for containership calling under multiple criteria decision-making environment.

In this paper, three alternative ports including the Port of Keelung, the Port of Taichung, and the Port of Kaohsiung are for further evaluation. The brief description of the three ports is shown as follows.

The Port of Kaohsiung in southern Taiwan is the largest international container port in Taiwan. The Port of Kaohsiung, established in 1863, has 26 container wharfs and more than 2,000 employees running the business. In recent years, the number of vessels visiting the Port of Kaohsiung was increasing, 
Table 4. Survey data for comparative weights for each sub-criteria.

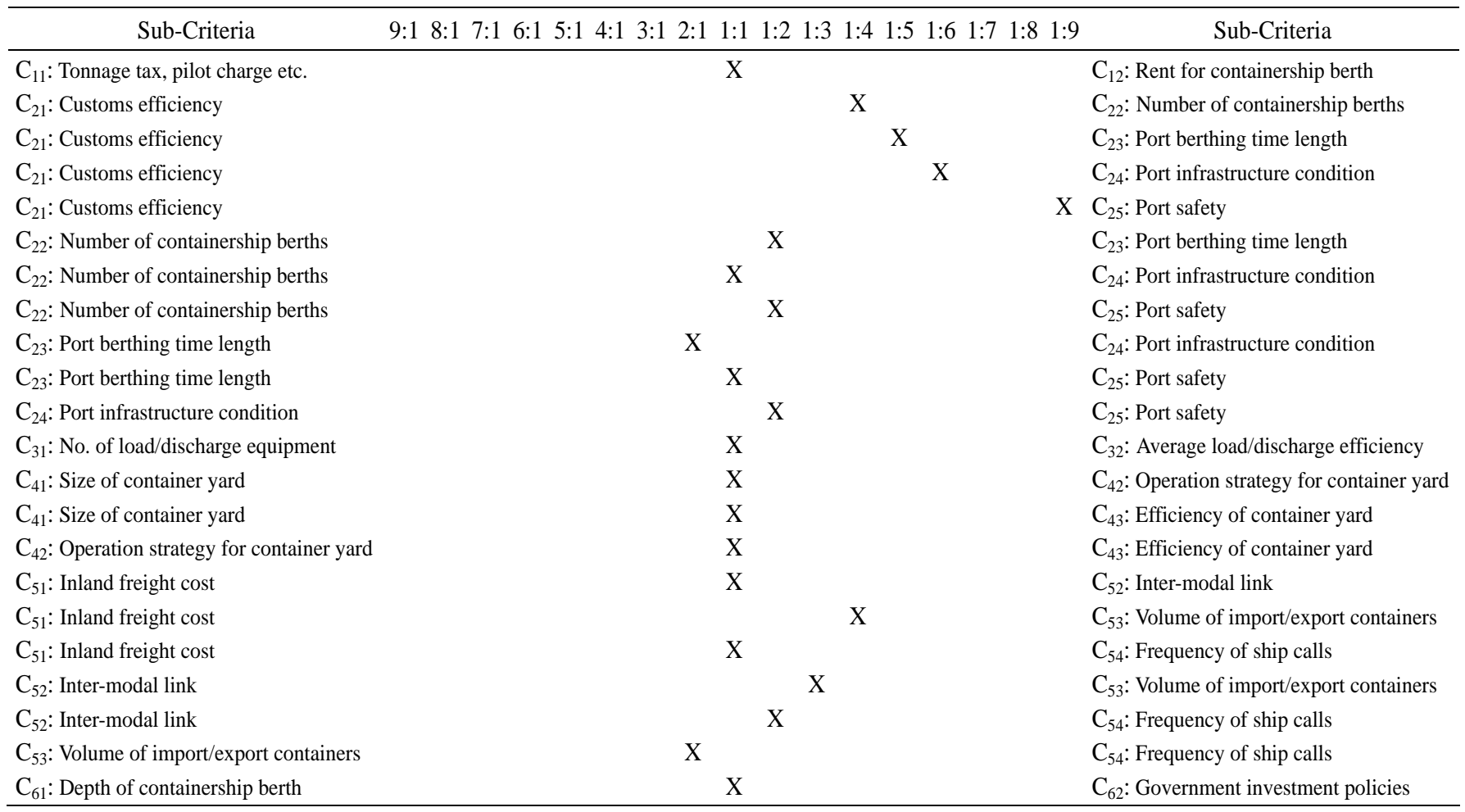

especially container vessels. Being pushed up by government investment, the total asset of the Port of Kaohsiung was increasing rapidly during the expansion period. In addition, the Port of Kaohsiung has high container handling efficiency, cheap transshipment costs, and excellent infrastructure conditions. The container volume of the Port of Kaohsiung was 9,676,555 TEU in 2008 .

The Port of Keelung in northern Taiwan is the second largest international container port in Taiwan. The Port of Keelung, established in 1886, has 15 container wharfs and more than 1,800 employees running the business. In recent years, the number of vessels visiting the Port of Keelung shows a slight increase. The total real asset of the Port of Keelung did not change significantly. In addition, the Port of Keelung has fair container handling efficiency, fair transshipment costs, and fair infrastructure conditions. In 2008, the container volume of the Port of Keelung was 2,055,259 TEU.

The Port of Taichung in center Taiwan is the third largest international container port in Taiwan. The Port of Taichung, established in 1984, has 7 container wharfs and more than 620 employees running the business. In recent years, the number of vessels visiting the Port of Taichung shows a slight increase. The total real asset of the Port of Taichung did not change significantly. In addition, the Port of Taichung has fair container handling efficiency, fair transshipment costs, and fair infrastructure conditions. The container volume of the Port of Taichung was 1,239,412 TEU in 2008.

\section{AHP Methodology}

Saaty [24] initially proposed the Analytic Hierarchy Process (AHP) for solving multiple criteria decision-making problems. Using a systematic hierarchy structure, the complex estimation criteria can be represented clearly and definitely. Ratio scales can be utilized to make reciprocal comparisons for each element and layer. After completing the reciprocal matrix, one can obtain comparative weights for each element.

Let's consider the criteria $C_{1}, \ldots \ldots, C_{i}, \ldots, C_{j}, \ldots . C_{n}$, someone level in the hierarchy. One wishes to find their weights of importance, $W_{1}, \ldots \ldots, W_{i}, \ldots, W_{j}, \ldots W_{n}$, on some elements in the next level. Allow $a_{i j}, i, j=1,2, \ldots, n$ to be the importance strength of $C_{i}$ when compared with $C_{j}$. Generally we can represent the comparative importance scale of criteria as shown in Table 5. The matrix of these numbers $a_{i j}$ is denoted $A$, or

$$
A=\left[\begin{array}{cccccc}
a_{11} & a_{12} & \ldots & a_{1 j} & \ldots & a_{1 n} \\
: & : & & : & & : \\
a_{i 1} & a_{i 2} & \ldots & a_{i j} & \ldots & a_{i n} \\
: & : & & : & & : \\
a_{n 1} & a_{n 2} & \ldots & a_{n j} & \ldots & a_{n n}
\end{array}\right]_{n \times n}
$$

where $a_{j i}=1 / a_{i j}$, that is, $A$ is reciprocal. If one's judgment is perfect in all comparisons, then $a_{i k}=a_{i j} \bullet a_{j k}$ for all $i, j, k$ and one calls the matrix $A$ consistent. An obvious case of a consistent matrix $A$ is its elements 
Table 5. Comparative importance scale of criteria.

\begin{tabular}{lll}
\hline Scale & Definition & Description \\
\hline 1 & Equally important & The importance of both comparative alternatives is equal \\
3 & Weakly important & Experience and judgment weakly tend to prefer one alternative \\
5 & Strongly important & Experience and judgment strongly tend to prefer one alternative \\
7 & Demonstrably important & Experience and judgment demonstrably tend to prefer one alternative \\
9 & Absolutely important & Experience and judgment absolutely tend to prefer one alternative \\
$2,4,6,8$ & Intermediate values & Need to compromise \\
& between adjacent judgment & \\
\hline
\end{tabular}

$$
a_{i j}=w_{i} / w_{j}, i, j=1,2, \ldots, n
$$

Thus, when the matrix $A$ is multiplied by the vector formed by each weighting $w=\left(w_{1}, w_{2}, \ldots . ., w_{n}\right)^{T}$, one gets

$A w=$

$$
\left[\begin{array}{cccccc}
w_{1} / w_{1} & w_{1} / w_{2} & \ldots & w_{1} / w_{j} & \ldots & w_{1} / w_{n} \\
w_{2} / w_{1} & w_{2} / w_{2} & \ldots & w_{2} / w_{j} & \ldots & w_{2} / w_{n} \\
: & : & & : & & : \\
w_{i} / w_{1} & w_{i} / w_{2} & & w_{i} / w_{j} & & w_{i} / w_{n} \\
: & : & & : & & : \\
w_{n} / w_{1} & w_{n} / w_{2} & \ldots & w_{n} / w_{j} & \ldots & w_{n} / w_{n}
\end{array}\right]_{n \times n}\left[\begin{array}{c}
w_{1} \\
w_{2} \\
: \\
w_{j} \\
\vdots \\
w_{n}
\end{array}\right]_{n \times 1}
$$$$
=n\left[\begin{array}{c}
w_{1} \\
w_{2} \\
: \\
w_{j} \\
\vdots \\
w_{n}
\end{array}\right]=n w
$$

Because $a_{i j}$ is the subjective ratings given by the decision-maker, there must be a distance between it and the actual values $w_{i} / w_{j}$. Thus, $A w=n w$ cannot be calculated directly. Therefore Saaty suggested using the maximum eigenvalue, $\lambda_{\max }=\frac{1}{n}\left(\frac{w_{1}^{\prime}}{w_{1}}+\frac{w_{2}^{\prime}}{w_{2}}+\ldots \ldots+\frac{w_{n}^{\prime}}{w_{n}}\right)$, of the solution of matrix $A$ to replace $n$, then

$$
A w=\lambda_{\max } w
$$

By this method, one can obtain the characteristic vector, referred to as the priority vector. Besides Saaty suggested the consistency index $\left(C . I=\frac{\lambda_{\max }-n}{n-1}\right)$ and the consistency rate $\left(C . R=\frac{C . I}{R . I}\right)$ to test the consistency of the intuitive judgment.
In general, it is satisfactory and accepted if the value of C.I. is about 0.1 and the value of C.R. is less than 0.1 .

\section{Solution Procedure}

The solution procedures for weights of the criteria and the sub-criteria are shown as follows. Assume there are $R$ candidate container ports $\left(A_{1}, A_{2}, \ldots A_{r} \ldots, A_{R}\right), M$ evaluation criteria $\left(C_{1}, C_{2}, \ldots C_{m}, \ldots, C_{M}\right)$ and $\sum_{m=1}^{M} \sum_{n=1}^{N} C_{m n}$ sub-criteria $\left(C_{11}\right.$, $\left.C_{12}, C_{21}, C_{22}, \ldots . ., C_{m n}, \ldots, C_{M N}\right) . W_{m}$ and $W_{m n}$ are the importance weights of $C_{m}$ and $C_{m n}$, respectively. According to the data obtained from the interview in Table 3, one can construct the matrix $A$ and further calculate the weight of every criteria $\left(W_{m}\right)$, the maximum eigenvalue $\left(\lambda_{\max }\right)$, the consistency index $(C . I)$ and the consistency rate $(C . R)$ as follows.

$A w=\left[\begin{array}{cccccc}1 & 4 & 3 & 4 & 5 & 1 / 8 \\ 1 / 4 & 1 & 1 / 2 & 1 & 2 & 1 / 9 \\ 1 / 3 & 2 & 1 & 2 & 3 & 1 / 8 \\ 1 / 4 & 1 & 1 / 2 & 1 & 4 & 1 / 8 \\ 1 / 5 & 1 / 2 & 1 / 3 & 1 / 4 & 1 & 1 / 9 \\ 8 & 9 & 8 & 8 & 9 & 1\end{array}\right]\left[\begin{array}{l}0.1758 \\ 0.0549 \\ 0.0888 \\ 0.0628 \\ 0.0311 \\ 0.5866\end{array}\right]=\left[\begin{array}{l}1.1419 \\ 0.3335 \\ 0.5495 \\ 0.4039 \\ 0.2042 \\ 3.9797\end{array}\right]$

$\lambda_{\max }=$

$\frac{1}{6}\left(\frac{1.1419}{0.1758}+\frac{0.3335}{0.0549}+\frac{0.5495}{0.0888}+\frac{0.4039}{0.0628}+\frac{0.2042}{0.0311}+\frac{3.9797}{0.5866}\right)$

$=6.4225$

$$
\begin{gathered}
C . I=\frac{\lambda_{\max }-n}{n-1}=\frac{6.4225-6}{6-1}=0.09 \\
C . R=\frac{C . I}{R . I}=\frac{0.09}{1.24}=0.07
\end{gathered}
$$

One can obtain the weights for criteria $C_{1}, C_{2}, C_{3}, C_{4}, C_{5}$, and $C_{6}$ are $W_{1}=0.1758, W_{2}=0.0549, W_{3}=0.0888, W_{4}=$ 
Table 6. Comparison of results for AHP approach with carriers' actual choices.

\begin{tabular}{|c|c|c|c|c|c|c|c|c|c|c|}
\hline \multirow[b]{2}{*}{ Port } & \multicolumn{2}{|c|}{ A marine carrier } & \multicolumn{2}{|c|}{$\mathrm{B}$ marine carrier } & \multicolumn{2}{|c|}{$\mathrm{C}$ marine carrier } & \multicolumn{2}{|c|}{ D marine carrier } & \multicolumn{2}{|c|}{ E marine carrier } \\
\hline & $\begin{array}{l}\text { AHP } \\
\text { result }\end{array}$ & $\begin{array}{l}\text { Actual } \\
\text { choice }\end{array}$ & $\begin{array}{l}\text { AHP } \\
\text { result }\end{array}$ & $\begin{array}{l}\text { Actual } \\
\text { choice }\end{array}$ & $\begin{array}{l}\text { AHP } \\
\text { result }\end{array}$ & $\begin{array}{l}\text { Actual } \\
\text { choice }\end{array}$ & $\begin{array}{l}\text { AHP } \\
\text { result }\end{array}$ & $\begin{array}{l}\text { Actual } \\
\text { choice }\end{array}$ & $\begin{array}{l}\text { AHP } \\
\text { result }\end{array}$ & $\begin{array}{l}\text { Actual } \\
\text { choice }\end{array}$ \\
\hline Port of Keelung & 0.2110 & & 0.1793 & & 0.1183 & & 0.1205 & & 0.4523 & $\mathrm{X}$ \\
\hline Port of Taichung & 0.1813 & & 0.0917 & & 0.0673 & & 0.0912 & & 0.2967 & \\
\hline Port of Kaohsiung & 0.6077 & $X$ & 0.7290 & $X$ & 0.8144 & $X$ & 0.7883 & $X$ & 0.2510 & \\
\hline
\end{tabular}

$0.0628, W_{5}=0.0311$ and $W_{6}=0.5866$, respectively. Similarly, using the same AHP approach and according to the data obtained from the interview in Table 4 , one can obtain the weights for sub-criteria $C_{11}, C_{12}, C_{21}, C_{22}, C_{23}, C_{24}, C_{25}, C_{31}$, $C_{32}, C_{41}, C_{42}, C_{43}, C_{51}, C_{52}, C_{53}, C_{54}, C_{61}$, and $C_{62}$, are $W_{11}=0.5$, $W_{12}=0.5, W_{21}=0.0399, W_{22}=0.1613, W_{23}=0.2936, W_{24}=$ $0.1749, W_{25}=0.3303, W_{31}=0.5, W_{32}=0.5, W_{41}=0.3333$, $W_{42}=0.3333, W_{43}=0.3333, W_{51}=0.1551, W_{52}=0.1401, W_{53}=$ $0.4854, W_{54}=0.2193, W_{61}=0.5$, and $W_{61}=0.5$, respectively.

The solution procedure for port choice is shown as follows. Let $P_{r m n}$ be the preference assigned to the $r^{\text {th }}$ candidate container port by the top decision maker under criteria $C_{m}$ and sub-criteria $C_{m n}$, where $1 \leq r \leq R, 1 \leq m \leq M, 1 \leq n \leq N$. The preference $P_{r m n}$ is based on a scale from 1-poor to 10-excellent. Let $P_{r}$ be the shipping company's total preference for the $r^{\text {th }}$ candidate container port.

$$
P_{r}=\sum_{m=1}^{M} \sum_{n=1}^{N} W_{m} \times W_{m n} \times P_{r m n}
$$

According to the above formula, we can obtain A Marine company's total preference for the first candidate port (Keelung port) as follows.

$$
\begin{aligned}
P_{1}= & 0.1758 \times 0.5 \times 5+0.1758 \times 0.5 \times 5+0.0549 \times 0.0399 \times 7 \\
& +0.0549 \times 0.1613 \times 5+0.0549 \times 0.2936 \times 7+0.0549 \\
& \times 0.1749 \times 6+0.0549 \times 0.3303 \times 5+0.0888 \times 0.5 \times 6 \\
& +0.0888 \times 0.5 \times 5+0.0628 \times 0.3333 \times 3+0.0628 \\
& \times 0.3333 \times 3+0.0628 \times 0.3333 \times 5+0.0311 \times 0.1551 \times 8 \\
& +0.0311 \times 0.1401 \times 5+0.0311 \times 0.4854 \times 9+0.0311 \\
& \times 0.2193 \times 4+0.5866 \times 0.5 \times 0+0.5866 \times 0.5 \times 4=3.3151
\end{aligned}
$$

The total preference for the second candidate port (Taichung port) is shown as follows.

$$
\begin{aligned}
P_{2}= & 0.1758 \times 0.5 \times 4+0.1758 \times 0.5 \times 4+0.0549 \times 0.0399 \times 7 \\
& +0.0549 \times 0.1613 \times 3+0.0549 \times 0.2936 \times 7+0.0549 \\
& \times 0.1749 \times 6+0.0549 \times 0.3303 \times 1+0.0888 \times 0.5 \times 4 \\
& +0.0888 \times 0.5 \times 4+0.0628 \times 0.3333 \times 6+0.0628 \\
& \times 0.3333 \times 3+0.0628 \times 0.3333 \times 5+0.0311 \times 0.1551 \\
& \times 6+0.0311 \times 0.1401 \times 5+0.0311 \times 0.4854 \times 2+0.0311 \\
& \times 0.2193 \times 2+0.5866 \times 0.5 \times 1+0.5866 \times 0.5 \times 3=2.8497
\end{aligned}
$$

The total preference for the third candidate port (e.g., Kaohsiung port) is shown as follows.

$$
\begin{aligned}
P_{3}= & 0.1758 \times 0.5 \times 9+0.1758 \times 0.5 \times 10+0.0549 \times 0.0399 \\
& \times 9+0.0549 \times 0.1613 \times 9+0.0549 \times 0.2936 \times 9+0.0549 \\
& \times 0.1749 \times 9+0.0549 \times 0.3303 \times 8+0.0888 \times 0.5 \times 9 \\
& +0.0888 \times 0.5 \times 9+0.0628 \times 0.3333 \times 9+0.0628 \times 0.3333 \\
& \times 10+0.0628 \times 0.3333 \times 8+0.0311 \times 0.1551 \times 3+0.0311 \\
& \times 0.1401 \times 5+0.0311 \times 0.4854 \times 5+0.0311 \times 0.2193 \times 9 \\
& +0.5866 \times 0.5 \times 10+0.5866 \times 0.5 \times 10=9.5495
\end{aligned}
$$

The preference rate for the Keelung port is 3.3151/ $(3.3151+2.8497+9.5495)=0.2110$. The preference rate for the Taichung port is $2.8497 /(3.3151+2.8497+9.5495)=$ 0.1813 . The preference rate for the Kaohsiung port is 9.5495/ $(3.3151+2.8497+9.5495)=0.6077$. Thus the top decision maker of A Marine Corp. company can rank quickly all candidate container ports and select easily the best one. The Kaohsiung port is selected as the best container port for callings.

Similarly, we can obtain B, C, D, and E shipping companies' preference rates for the Keelung port, the Taichung port, and the Kaohsiung port in Table 6 . Table 6 provides a comparison of the results for AHP model with the actual port choices of shipping companies. The result comparison shows that this AHP model seems to be promising.

\section{DISCUSSION}

Selecting an optimal port for containership's callings is a complex decision-making problem involving many aspects e.g., costs, port's conditions, hinterland economy and issues of a shipping company's operation strategies. In this study, we constructed an AHP model for simulating the behaviors of port choices of shipping carriers. This hierarchical analysis structure for the AHP model defined six first-tier goals: (a) port charge, tax, rent and cost, (b) port operation efficiency, (c) port loading/discharging efficiency, (d) size and efficiency of container yard, (e) hinterland economy and (f) depth of berth.

In this study, the utilization of this proposed AHP model is demonstrated with a case study of five shipping companies. The five shipping companies were categorized into two groups: (a) the oceangoing route group including A, B, C, and D Marine Corporations who operates Asia-European, Asia-America and America-European oceangoing routes, and (b) the inter-Asia coasting group including E Lines Ltd. who almost operates Southeast Asia-Northeast Asia inert-Asia routes. This study found that the importance weights of influential 
Table 7. The differences between coasting carriers and oceangoing carriers in the port choices.

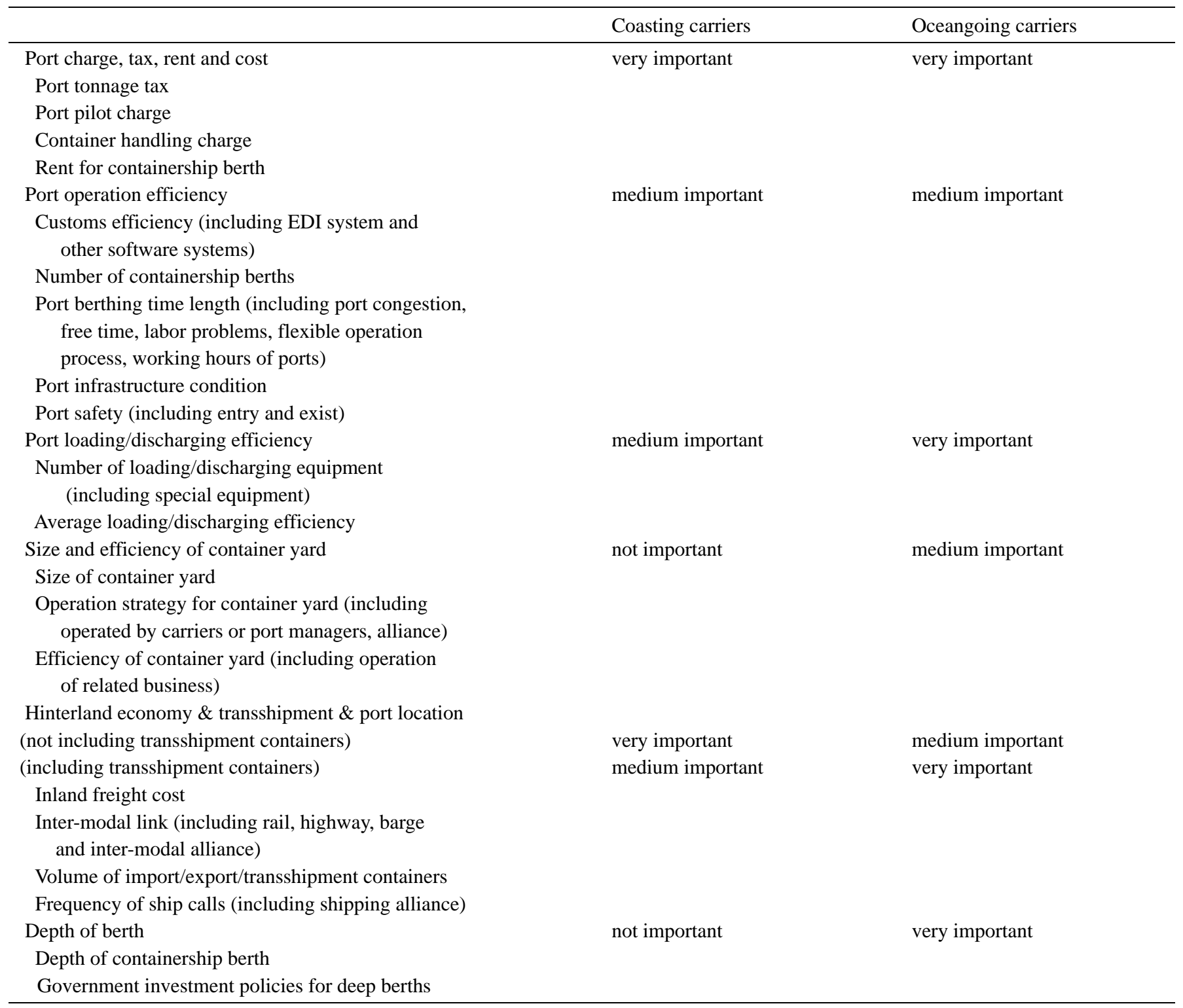

factors in the coasting carriers' port choices are different from those of influential factors in the oceangoing carriers' port choices. The differences between the port choice behaviors of coasting carriers and oceangoing carriers are identified below and summarized in Table 7.

(1) There exists a consensus of the ranking preference among four of these five shipping companies, namely A, B, C, and D Marine Corporations, regarding the priorities of these six first-tier goals. The ranks preferred by these four shipping companies who operate oceangoing routes is as follows: (a) depth of containership berth; (b) port charge, tax, rent and cost; (c) port loading/discharging efficiency; (d) size and efficiency of container yard; (e) port operation efficiency; (f) hinterland economy (not including trans- shipment). In most cases, the importance of the depth of containership berth, port charge, tax, rent and cost, and port loading/discharging efficiency is much higher than that of the other three goals.

(2) The ranks preferred by this coasting route group, namely, E Lines Ltd. is as follows: (a) hinterland economy; (b) port charge, tax, rent and cost; (c) port loading/discharging efficiency; (d) port operation efficiency; (e) size and efficiency of container yard; (f) depth of containership berth. In most cases, the importance of the hinterland economy, port charge, tax, rent and cost, port loading/discharging efficiency is much higher than that of the other three goals.

(3) The oceangoing route groups, namely A, B, C, and D Marine Corporations, most favor the port of Kaohsiung and least favor the port of Taichung and the port of Keelung for 
callings. Choosing the port of Kaohsiung as their most favorable port is an indication that all oceangoing route groups usually operate large vessels and need deep containership berths for calling. In other words, the depth of containership berth is the oceangoing route groups' main concern. The reasons why the port of Keelung and the port of Taichung came out as the last could be that the depths of containership berths are not enough deep for large vessels to call.

(4) The coasting route group, namely E Lines Ltd., most favor the port of Keelung and least favor the port of Taichung for callings. Choosing the port of Keelung as their most favorable port is an indication that all coasting route groups tried to avoid any inland freight cost. In other words, the hinterland economy is the coasting route groups' main concern. The reasons why the port of Keelung came out as the first could be that the hinterland economy of the Keelung port is more than those of the Taichung port and the Kaohsiung port.

In addition, more detailed discussions are presented as follows. In today's marine market, the "transshipment" issue is one of the important influential factors in the carriers' port choices. To attract more large containerships and super postPanamax container vessels to call, the ports of Keelung, Taichung and Kaohsiung in Taiwan always want to become the transshipment hubs. The basic infrastructure condition for transshipment hub is the deepwater berth. The deepwater berth development plan of the Keelung port is restricted by the coast geography condition. It is difficult for the Keelung port to build deepwater berths. Besides the inland traffic congestion problem around the Keelung port is terrible. The small capacities of container yards in the Keelung port are not enough for handing a lot of transshipment containers. The navigation channel around the Taichung port often silted up. It is difficult for the Taichung port to dredge and build deepwater berths. On the contrary, the Kaohsiung port built several deepwater berths in the past few years. Thus many shipping companies did not choose the Keelung port and Taichung port, but choose the Kaohsiung port as a transshipment hub for collecting and distributing international trade containers from/to Southeast Asia countries, and assign their container vessels to call the Kaohsiung port. That is why the volume of transshipment containers of the Kaohsiung port increased rapidly in the past few years. In Table 1 , it is noted that the volume $(5,085,888 \mathrm{TEU})$ of transshipment containers is almost $52 \%$ of total loading/discharging volume $(9,774,670$ TEU) of import, export and transshipment containers in 2006.

The hinterland economy of Keelung port in the North Taiwan is almost $42 \%$ of the total Taiwanese economy. Thus a lot of international trade containers including the coasting containers and the oceangoing containers are from/to the North Taiwan area. The Keelung port should be the most favorable one for carriers because it is the nearest port for exporting/importing the containers from/to the North Taiwan area. But there are still a lot of oceangoing containers from/to the North Taiwan area to be exported/imported via the Kaohsiung port in the South Taiwan area. Because the inland freight costs of oceangoing containers transported from the North Taiwan area to the Kaohsiung port in South Taiwan are less than the sea freight revenues of these oceangoing containers, also less than the daily operating cost saving of a large containership calling at the Kaohsiung port. Another potential reason is that the Kaohsiung port gives the carriers the rent incentive for specific container wharfs (including containership berth) operated by carriers. That is, the carrier pays the Kaohsiung port the fixed rent for one specific container wharf and berth per year, and the carrier can load/discharge freely containers. In order to reduce the loading/charging container cost per TEU by increasing the total volume of containers, the carrier always exports/imports the international trade containers from/to the North Taiwan area via the Kaohsiung port.

The hinterland economy of Taichung port is less than those of the Keelung port and the Kaohsiung port. Besides the numbers of containership berths of Keelung port and Kaohsiung port are more than that of the Taichung port. The Taichung port is always not the most favorable port for calling.

The objective of carriers' business strategy is to maximum the profit. The Kaohsiung port is always the most favorable one and carriers always choose the Kaohsiung port for calling and loading/discharging the international trade export/import containers from/to Taiwan and the transshipment containers from/to the Southeast Asia region. The Keelung port is one of the most favorable ports for coasting carriers. To save inland freight cost, many coasting carriers always choose the Keelung port for calling and loading/discharging the coasting containers from/to the North Taiwan area. The Taichung port is not one of the most favorable ports for carriers. Only a few of coasting carriers choose the Taichung port for calling and loading/discharging the coasting containers from/to the Center Taiwan area.

\section{CONCLUSION}

In this paper, we developed an AHP model for the selection of container ports in the multiple-ports region. The utilization of this proposed AHP model is demonstrated with a case of five shipping companies and the results showed that the AHP model seems to be promising. In the past, a number of studies have identified the influential factors affecting carriers' port choices, but few researchers have further examined the weight of every influential factor. This paper used the AHP approach to calculate the weight of every influential factor to reveal the concerns and preferences of those oceangoing route shipping companies and coasting route shipping companies. This paper fills the gap in the existing literature by establishing an AHP model for the port choice. According to the results for the AHP model, some suggestions are provide as follows. The oceangoing route carriers' main concerns are (a) depth of containership berth; (b) port charge, tax, rent and cost; (c) port 
loading/discharging efficiency. In order to keep the existing oceangoing route carriers and attract more new oceangoing route carriers, the managers of ports should build new the deepwater berths, reduce the port charges, taxes, rents and costs, and improve the port loading/discharging efficiency. The coasting route carriers, main concerns are (a) hinterland economy; (b) port charge, tax, rent and cost; (c) port loading/ discharging efficiency. In order to keep the existing coasting route carriers and attract more new coasting route carriers, the managers of ports should reduce the port charges, taxes, rents and costs, and improve the port loading/discharging efficiency. The dramatic rapid growth of the hinterland economy is difficult in the short-term period. The growth of the hinterland economy could be an important long-term goal.

\section{REFERENCES}

1. Brian, S., "Containerization: inter-port competition and port selection," Maritime Policy and Management, Vol. 12, No. 4, pp. 293-303 (1985).

2. Brooks, M., Sea Change in Liner Shipping Regulation and Management Decision-making in a Global Industry, Elserier Science Ltd, Oxford, U.K. (2000).

3. Chang, Y. T., Lee, S.Y., and Tongzon, J. L., "Port selection factors by shipping lines: different perspectives between trunk liners and feeder service providers," Marine Policy, Vol. 32, No. 6, pp. 877-885 (2008).

4. Chou, C. C., "Analysis of container throughput of major ports in Far Eastern," Marine Research Journal, Vol. 12, pp. 57-72 (2002).

5. Chou, C. C., "Using analytic hierarchy process approach in the selection of container port in the multiple-ports region," in: Transportation Research Board Annual Meeting (2005).

6. Chou, C. C., "A fuzzy MCDM method for solving marine transshipment container port selection problems," Applied Mathematics and Computation, Vol. 186, No. 1, pp. 435-444 (2007)

7. Chou, C. C., Chu, C. W., and Liang, G. S., "A transportation demand split model for international ports," Journal of the Eastern Asia Society for Transportation Studies, Vol. 5, No. 1, pp. 625-637 (2003).

8. Chou, C. C., Chu, C. W., and Liang, G. S., "Competitiveness analysis of major ports in eastern Asia," Journal of the Eastern Asia Society for Transportation Studies, Vol. 5, No. 1, pp. 682-697 (2003).

9. Chou, C. C., Chu, C. W., and Liang, G. S., "Comparison of two models for port choice," Maritime Quarterly, Vol. 12, No. 3, pp. 45-62 (2003).

10. Chou, C. C., Chu, C. W., and Liang, G. S., "A modified regression model for forecasting the volume of Taiwan's import containers," Mathematical and Computer Modelling, Vol. 47, pp. $797-807$ (2008).

11. Chu, T. C. and Lai, M. T., "Selecting distribution centre location using an improved fuzzy MCDM approach,” International Journal of Advanced Manufacturing Technology, Vol. 26, pp. 293-299 (2005).

12. Dahlberg, M. D. and May, J. H., "Linear programming for sitting of energy facilities," Journal of Energy Engineering, Vol. 106, pp. 5-14 (1980).

13. Ernst, G. F., "Economics of transportation in container shipping logistics," in: International Conference on Port and Maritime $R \& D$ and Technology, Singapore (2001).
14. Farahani, R. Z. and Asgari, N., "Combination of MCDM and covering techniques in a hierarchical model for facility location," European Journal of Operational Research, Vol. 176, pp. 1839-1858 (2007).

15. Hayuth, Y., "Container traffic in ocean shipping policy," in: International Conference on Ports for Europe, Brugge (1980).

16. Hwang, C. L. and Yoon, K., Multiple Attributes Decision Making Methods and Applications, Springer-Verlag, Berlin Heidelberg (1981).

17. James, B. and Gail, B., "The perception of route competition via seaports in the European communities research project part 1," Maritime Policy and Management, Vol. 15, No. 1, pp. 35-55 (1988).

18. Jansson, J. O. and Shneers, D., Liner Shipping Economics, Chapman and Hall Ltd, New York (1987).

19. Kuo, M. S., Tzeng, G. H., and Huang, W. C., "Group decision-making based on concepts of ideal and anti-ideal points in a fuzzy environment," Mathematical and Computer Modelling, Vol. 45, pp. 324-339 (2007).

20. Kuo, T. C. and Chu, C. W., "A decision-making model for the selection of calling container port," in: The 5th Symposium on Transportation Network, Taiwan, R.O.C. (2000).

21. Malchow, M. B. and Kanafani, A., "A disaggregate analysis of port selection," Transportation Research Part E, Vol. 40, pp. 317-337 (2004).

22. Mourmouris, J. C., "MCDM for location and evaluation of waste disposal facilities in metropolitan areas: the case of East Attica," International Journal of Environment Technology and Management, Vol. 6, pp. 180192 (2006).

23. Rietveld, P. and Ouwersloot, H., "Ordinal data in multi-criteria decision making, a stochastic dominance approach to sitting nuclear power plants," European Journal of Operational Research, Vol. 56, No. 2, pp. 249-262 (1992).

24. Saaty, T. L., The Analytic Hierarchy Process, N.Y. McGraw-Hill (1980).

25. Spohrer, G. A. and Kmak, T. R., "Qualitative analysis used in evaluating alternative plant location scenarios," Industrial Engineering, Vol. 16, No. 8, pp. 52-56 (1984).

26. Sternberg, R. W., "The successful factors of an ocean transshipment center, the case study of one Italian port," The Journal of Chinese Ports, Vol. 29, No. 2, pp. 13-18 (2000).

27. Stevenson, W. J., Production/Operation Management, Richard D. Irwin Inc., Illinois (1993).

28. Tabari, M., Kaboli, A., Aryanezhad, M. B., Shahanaghi, K., and Siadat, A., "A new method for location selection: a hybrid analysis," Applied Mathematics and Computation, Vol. 206, pp. 598-606 (2008).

29. Thomson, B. J., "Structure changes in the maritime industry's impact on the inter-port competition in container trade," in: International Conference on Shipping Development and Port Management (1998).

30. Tompkins, J. A. and White, J. A., Facilities Planning, John Wiley \& Sons Company, New York (1984).

31. Tongzon, J. L., "Port choice and freight forwarders," Transportation Research Part E-Logistics and Transportation Review, Vol. 45, No. 1, pp. 186-195 (2009).

32. Tongzon, J. L. and Sawant, L., "Port choice in a competitive environment: from the shipping lines' perspective," Applied Economics, Vol. 39, No. 4-6, pp. 477-492 (2007).

33. Yang, Z., "Analysis of container port policy by the reaction of an equilibrium shipping market," Maritime Policy and Management, Vol. 26, No. 4, pp. 369-381 (1999). 